\title{
THE INFLUENCE OF LIQUIDITY, CAPITAL STRUCTURE, PROFITABILITY AND CASH FLOWS ON THE COMPANY'S FINANCIAL DISTRESS
}

\author{
MUHAMMAD REZA FAHLEVI \\ AAN MARLINAH \\ Trisakti School of Management \\ rezafahlevi417@gmail.com \\ aanmaryam@stietrisakti.ac.id
}

\begin{abstract}
Financial distress is a complicated phase and multidimensional problem facing by the company. Since it leads the company on the possibility of bankruptcy, this situation needs immediately to be recovered. This study aims to determine the factors that influence the company's financial distress. There are ten variables in this study which are classified into four categories: liquidity, capital structure, profitability and cash flows. This study used financial statement data of manufacturing company which is listed in Indonesia Stock Exchange during the threeyear study period from 2011 to 2013. There are some criteria in choosing the representative sample so that the sum of the companies are 90 companies or equal to 270 financial statements data. The empirical findings show that there are only three variables that influence the company's financial distress. The significant variables are current ratio (liquidity), return on assets (profitability) and cash flow ratio (cash flow).
\end{abstract}

Keywords: $\quad$ Financial Distress, Liquidity, Capital Structure, Profitability, Cash Flows.

Abstrak: Kesulitan keuangan adalah fase rumit dan masalah multidimensi yang dihadapi oleh perusahaan. Hal ini mengarahkan perusahaan pada kemungkinan kebangkrutan, situasi ini perlu segera dipulihkan. Penelitian ini bertujuan untuk mengetahui faktor-faktor yang mempengaruhi kesulitan keuangan perusahaan. Ada sepuluh variabel dalam penelitian ini yang diklasifikasikan ke dalam empat kategori: likuiditas, struktur modal, profitabilitas, dan arus kas. Penelitian ini menggunakan data laporan keuangan perusahaan manufaktur yang terdaftar di Bursa Efek Indonesia selama periode studi tiga tahun dari 2011 hingga 2013. Ada beberapa kriteria dalam memilih sampel yang representatif sehingga jumlah perusahaan adalah 90 perusahaan atau sama dengan 270 data laporan keuangan. Temuan empiris menunjukkan bahwa hanya ada tiga variabel yang mempengaruhi kesulitan keuangan perusahaan. Variabel signifikan adalah rasio lancar (likuiditas), pengembalian aset (profitabilitas) dan rasio arus kas (arus kas).

Kata kunci: Kesulitan keuangan, likuiditas, struktur modal, profitabilitas, arus kas

\section{INTRODUCTION}

Europe's economic crisis in 2008 has a comprehensive impact to various sectors until now. This crisis has globalized to other countries outside the European Union, many countries are also feeling the significant impact. In Indonesia, the impact is not directly suffered. The indirect impacts felt through China since China is the largest importer of Indonesia. Nowadays, the 
countries around the world are still continuing to improve themself to recover from the crisis.

The declining confidence level of investment can be seen from the decline in $\mathrm{JCl}$ (Jakarta Composite Index) when the crisis occurs, of positions 2,971 to 2,514. The Indonesian capital market is depended with foreign investment, thus the global issue will probably attack economic condition in Indonesia. Likewise, the Indonesian manufacturing sector has been affected by such condition, considering that the manufacturing sector has a large portion in the formation of $\mathrm{JCl}$ value. This is also reflected from the threat of non-oil trade deficit, when import is rising day to day and export performance is slacking. Consequently, the inflation price of raw material due to rupiah weakened is inevitable, from around 9,300 at the beginning of January and ended around 11,500 at the end of December 2008. This situation is getting worse until 2015 when the foreign exchange hits 13,000 for the first time in history.

Therefore, it is important for all sectors, especially manufacturing companies, to evaluate their survival rate at the time of crisis and years after the crisis. The declining profit and performance suffered by the companies are irresistible results. This issue should be dealt seriously by stakeholders. Companies that are not able to improve their performance will experience financial distress and eventually goes to bankruptcy (Hapsari, 2012).

Financial distress can happen either by external factors or internal factors. External factors, such as global economic crisis, is a major aspect beyond company's control. Whereas internal factors such as poor management, unwise business expansion, fierce competition, high debt financing, and unfavorable contracts are aspects under company's control (Emery et al., 2007 in Juniarti, 2013). Accordingly, both internal and external factors will bring out deterioration in company's operation.
There are many notions related to financial distress, but financial distress can be generally stated as unhealthy phased facing by the company. A healthy company should not have any problems with its activities, especially financial problems. Financial distress can begin from liquidity problem (short-term) which is the lightest level of financial difficulties, up to the declaration of bankruptcy which is the most severe difficulties. So that financial distress can be seen as a long continuum rather than temporary problem (Saleh and Sudiyanto 2013).

Financial distress can be seen as a phase just before the bankruptcy and occur when the company bears net loss from year to year (Hapsari, 2012). Symptoms of financial distress can begin integrally when there is early impairment of revenue for more than $20 \%$, deterioration when profit decreased more than $20 \%$, and finally cash flow problem when operating cash flow becomes negative (Pranowo, 2010). Furthermore, based on Brahmana (2007) in Hidayat and Meiranto (2014), a company can be categorized into financial distress condition if has negative operating profit, negative net income, negative book value of equity, and exercise merger. Therefore, to determine whether a company in the condition of financial distress or not, it is quite difficult to judge from one perspective. For instance, financial distress is multidimensional problem and complicated situation.

Financial distress has become a topic that continues to be studied through years. Many models have been developed to analyze the condition of financial distress. The popular multivariate model (discriminant analysis) had been developed by Altman (1968). This model is widely known as Altman Z-score model. Under this method, sets of required financial ratio is collected to obtain the prediction model. After prediction model is obtained, it is becoming easy to determine the condition of a company. If the value of Z-score falls under 1.81, then the company is classified into the distress zone. If the value of Z-score falls over 2.99, then the 
company is classified into safe zone. Whereas the value of Z-score falls between 1.81 and 2.99, then the company is classified into grey zone. Altman had discovered several financial ratios which can be used as indicators of bankruptcy prediction in his model, the ratios are: working capital to total assets, retained earnings to total assets, earnings before interest and taxes to total assets, market value of equity to book value of total debt, and sales to total assets.

Other popular multivariate model is logit model or binary logistic model. This model uses predictor variable to determine any influence against dependent variable. Based on Kasgari et al. (2013), logit model is the development of multiple regression in dependent variable where variables are not linked. Logit model is probable logarithm where the financial distress or nonfinancial distress events may happen. The result of logistic regression is the possibility if predictor variable changes, does it affect the change of dependent variable or not. Ohlson (1980) had developed this model by using nine independent variables, namely size of company, total liabilities to total assets, working capital to total assets, current liabilities to total assets, net income to total assets, operating cash flow to total liabilities, changes in net income, and two dummy variables.

Although many predictions model have been developed year to year, the main purpose is to recover the company's condition immediately. The ultimate benefit in analyzing company's financial distress is to take corrective actions to restore company's going concern. The early warning system must be developed to identify and restore the company's condition (Almilia, 2006). In addition, early warning system facilitates stakeholders to make quick responses to reduce the cost of bankruptcy (Endri, 2009). The other potential useful of bankruptcy prediction, besides internal business consideration or credit evaluation, is to screen out undesirable investment (Altman, 1968).

\section{Hypothesis Development}

Analysis of liquidity can be carried out to see the company's ability to survive in the short term period. Liquidity is the ability to convert assets into cash or to obtain cash to meet current liabilities (Subramanyam and Wild, 2009, 528). Financial distress is used to reflect the existence of these liquidity problems. Based on Hapsari (2012), financial distress is a severe liquidity problem and company cannot solve it, but it does not require changes in operating size or company's structure. In other words, the liquidity problem is the initial estimates to detect the financial distress condition. Therefore, the first hypothesis of this research can be inferred as follows:

$\mathrm{H}_{1}$ Liquidity can influence the company's financial distress.

Furthermore, capital structure or financial leverage is another important factor in assessing the condition of financial distress. When a company is relying more on debtfinancing rather than shares (equity-financing), the risk of repayment difficulties will occur in the future. This happens because the bankruptcy is usually preceded by the occurrence of default, so that the greater the amount of debt, the higher the probability of companies experiencing financial distress (Pasaribu, 2008). Therefore, the second hypothesis of this research can be inferred as follows:

$\mathrm{H}_{2}$ Financial leverage can influence the company's financial distress.

Moreover, the settlement of both current and long-term debt can be perceived by how much profit is generated. The higher the rate of return, will cause the better signal for all parties. The companies will have more ability to repay their obligations, while investors and creditors are given a sense of security. Analysts often use profitability base as a reliable test to measure effectivity of company's operation (Weygandt et al., 2013). Thus, the profitability of the company 
is the next factor which is associated with the company's financial distress. Therefore, the third hypothesis of this research can be inferred as follows:

$\mathrm{H}_{3}$ Profitability can influence the company's financial distress.

Finally, the last factor which contributes to detect the company's financial distress is cash flow. Cash flow gives a vivid description of the short-term corporate health condition. Cash flows explain the availability of cash to repay obligations. According to Atieh (2014), operating cash flow gives a better picture about the quality of the company's profit because it does not involve revenues and expenses, which calculated on an accrual basis and involved subjective assumptions. Therefore, operating cash flows has a close relationship in assessing the condition of financial distress. Therefore, the last hypothesis of this research can be inferred as follows:

$\mathrm{H}_{4}$ Cash flows can influence the company's financial distress.

Based on the explanations above, we can conclude that there are four basic elements which may cause the occurrence of financial distress. Those variables are common elements in almost journals related to financial distress condition or bankruptcy prediction.

\section{Previous Research}

The previous research, which become a cornerstone of this research, had been predicting financial distress by using 24 financial ratios. The study was carried out by Al-khatib and Al-Horani (2012) using a sample of firms listed on the Amman Stock Exchange (Jordan) and taking period since 2007 to 2011. The results of this study show that the ratio of return on assets and return on equity are influential in predicting financial distress. In addition, this study also compared the discriminant analysis and logistic regression method. The results suggest that both methods can be used to predict the company's financial distress.

This study is a replication of the previous study by reducing the number of independent variables and using only single method, logistic regression. There are differences from previous studies in the addition of two new independent variables. The two new independent variables are cash flow ratio and operating cash margin (Atieh 2014 and Pasaribu 2008).

\section{RESEARCH METHODS}

The type of this research is causality research (causal study). The study period is from 2011 to 2013, three years of study periods. The sample is manufacturing companies listed in Indonesia Stock Exchange since 2009 to 2013 with purposive sampling method as sample selection technique. After the sampling process, the sum of companies that meet the criteria for the study are 90 companies. The results of the sample selection can be seen in the following table. 
Table 1 Sample Selection

\begin{tabular}{clcc}
\hline No & \multicolumn{1}{c}{ Criteria } & $\begin{array}{c}\text { Sum of the } \\
\text { companies }\end{array}$ & $\begin{array}{c}\text { Sum of the } \\
\text { data }\end{array}$ \\
\hline 1 & $\begin{array}{l}\text { Manufacturing companies which are } \\
\text { listed in Indonesian Stock Exchange } \\
\text { from 2009 until 2013. }\end{array}$ & 116 & 348 \\
$2 \quad \begin{array}{l}\text { Manufacturing companies which do } \\
\text { not use December 31 as their fiscal } \\
\text { year. }\end{array}$ & $(4)$ & $(12)$ \\
$3 \quad \begin{array}{l}\text { Manufacturing companies which do } \\
\text { not use Rupiah as their original } \\
\text { currency. }\end{array}$ & $(22)$ & $(66)$ \\
Total sample selected & 90 & 270 \\
\hline
\end{tabular}

The dependent variable in this research is financial distress which is dummy variable. In this study, financial distress is measured by average earnings per share for three years, or equals to study periods. Specifically, the companies that are experiencing financial distress if has an average earnings per share over the last three years is under one. Whereas for a successful company or non-financial distress if has an average earnings per share over the last three years is greater than one (Alkhatib and Al-Horani, 2012).

According to Bodroastuti (2009) in Saleh and Sudiyanto (2013), earnings per share is the most widely ratio used by the shareholders to assess the future prospects of the company in comparison to other financial ratios. If the earnings per share has a tendency to decrease or negative from year to year in the study period, it will probably reflect the company's internal financial problems so that earnings per share is not as big as expected. Thus, average earnings per share can be a reliable indicator to determine company's financial distress because of three years duration to derive this amount, since as stated before, the financial distress can be seen as a prolonged problem rather than short-term problem (Almilia and Kristijadi, 2003).

The independent variables are encompassed into four aspects. The liquidity aspects are represented by current ratio and working capital ratio. The capital structure aspects are represented by debt to asset ratio and current liabilities to assets ratio. For profitability aspects, the return on assets, return on equity, net profit margin, and the total asset turnover are used. The last aspects of cash flows are represented by cash flow ratio and operating cash margin. Thus, this study uses 10 independent variables and single dependent variable which are explained in the greater detail as follows: 
Table 2 Variable Measurement

\begin{tabular}{|c|c|c|c|}
\hline No. & Name & Measurement & Explanation \\
\hline 1 & $\begin{array}{l}\text { Financial Distress } \\
\text { (Average EPS) }\end{array}$ & $\frac{E P S(t)+E P S(t-1)+E P S(t-2)}{3}$ & $\begin{array}{l}\text { If the value is less than one, } \\
\text { the company suffers financial } \\
\text { distress. }\end{array}$ \\
\hline 2 & Working capital ratio & Current Assets - Current Liabilities & It measures the net liquidity \\
\hline & vruining capitar talio & Total Assets & relatives to total capitalization \\
\hline 3 & Current ratio & $\frac{\text { Current Assets }}{\text { Current Liabilities }}$ & $\begin{array}{l}\text { It evaluates the level of } \\
\text { liquidity to meets current } \\
\text { liabilities. }\end{array}$ \\
\hline 4 & Debt to assets ratio & $\frac{\text { Total Liabilities }}{\text { Total Assets }}$ & $\begin{array}{l}\text { It measures how many debt- } \\
\text { financing occurs in company } \\
\text { (financial leverage) }\end{array}$ \\
\hline 5 & $\begin{array}{l}\text { Current liabilities to } \\
\text { assets ratio }\end{array}$ & $\frac{\text { Curren Liabilities }}{\text { Total Assets }}$ & $\begin{array}{l}\text { It measures financial leverage } \\
\text { based on short term } \\
\text { standpoint }\end{array}$ \\
\hline 6 & Return on assets & $\frac{\text { Profit after tax }}{\text { Total Assets }}$ & $\begin{array}{l}\text { It measures overall profitability } \\
\text { relatives to total assets. }\end{array}$ \\
\hline 7 & Return on equity & $\frac{\text { Profit after tax }}{\text { Equity }}$ & $\begin{array}{l}\text { It measures profitability based } \\
\text { on common equity. }\end{array}$ \\
\hline 8 & Net profit margin & $\frac{\text { Profit after tax }}{\text { Sales }}$ & $\begin{array}{l}\text { It indicates the net profitability } \\
\text { over the sales for one } \\
\text { operation cycle. }\end{array}$ \\
\hline 9 & $\begin{array}{l}\text { Total assets } \\
\text { turnover }\end{array}$ & $\frac{\text { Sales }}{\text { Total Assets }}$ & $\begin{array}{l}\text { It indicates how much assets } \\
\text { can generate sales. }\end{array}$ \\
\hline 10 & Cash flow ratio & $\frac{\text { Net Operating Cash Flows }}{\text { Total Current Liabilites }}$ & $\begin{array}{l}\text { It measures the availability of } \\
\text { operating cashflow to fulfil } \\
\text { short term liabilities. }\end{array}$ \\
\hline 11 & $\begin{array}{l}\text { Operating cash } \\
\text { margin }\end{array}$ & $\frac{\text { Net Operating Cash Flows }}{\text { Net Sales }}$ & $\begin{array}{l}\text { It measures how much net } \\
\text { operating cashflow can be } \\
\text { generated from its sales. }\end{array}$ \\
\hline
\end{tabular}

This research is using logistic regression as analytical method. Logistic regression and discriminant analysis is actually similar. Both methods are used if we want to test whether the probability of the dependent variable can be predicted by the independent variables. Logistic regression analysis does not require the assumption of normality on the variables (Ghozali, 2013). This research also involves several sets of analytical test associated with logistic regression method which explained later.

\section{ANALYSIS AND RESULTS}

Descriptive statistics table for the independent variables can be used see the number of samples, the minimum value, maximum value, average value (mean) and standard deviation. Descriptive statistical analysis is used to provide an overview and description of the data in the study. Here is the presentation of the descriptive statistics result. 
Table 3 Descriptive Statistics

\begin{tabular}{cccccc}
\hline Variable & $\begin{array}{c}\text { Total } \\
\text { data }\end{array}$ & Minimum & Maximum & Mean & $\begin{array}{c}\text { Standard } \\
\text { Deviation }\end{array}$ \\
\hline Working Capital Ratio & 270 & -0.7208 & 0.8133 & 0.208734 & 0.2719778 \\
Current Ratio & 270 & 0.2130 & 247.4441 & 3.304404 & 15.07441716 \\
$\begin{array}{c}\text { Debt to Total Asset } \\
\text { Current Liabilities to Total }\end{array}$ & 270 & 0.0372 & 3.0807 & 0.523530 & 0.4043972 \\
Asset & 270 & 0.0025 & 1.5486 & 0,336357 & 0,2136365 \\
Return on Asset & 270 & -0.7558 & 0.4162 & 0.060092 & 0.1216698 \\
Return on Equity & 270 & -7.6848 & 3.2463 & 0.078678 & 0.6345298 \\
Net Profit Margin & 270 & -9.3959 & 0.8187 & -0.033303 & 0.6819871 \\
Total Asset Turnover & 270 & 0.0150 & 2.9577 & 1.113190 & 0.5622440 \\
Cash Flow Ratio & 270 & -2.0369 & 82,4697 & 0.613319 & 5,0321982 \\
Operating Cash Margin & 270 & $-4,4232$ & 0,4635 & 0,008333 & 0,3661721 \\
\hline
\end{tabular}

Based on the table, the magnitude of the difference in -2 log likelihood value in both blocks is 167.169 . The declining value that occurred from block number: 0 to block number: 1 indicates that the addition of independent variables in the model will improve the model fit. Therefore, the logistic regression model is fit for use in further testing. Nagelkerke $\mathrm{R}^{2}$ value is amounting 0.791 . This value indicates that the variation in the dependent variable, the condition of the company's financial distress, which can be explained by the ten independent variables is $79.1 \%$. The remaining $20.9 \%$ is explained by other factors that are not included in the model. Based on the above data, the Sig. amounted to 0.991. Value Sig. is greater than 0.05 , which means that the regression model is acceptable. Thus, the regression model is able for prediction or in accordance with the value of its observations. Based on the results of SPSS output, it can be seen that there are 43 data that are experiencing financial distress. However, the exact prediction by the model only 33 data. The level of classification accuracy was $76.7 \%$. The remaining 10 data are improperly predicted by the model. This amount is equivalent to $3.7 \%$ and referred as type 1 error. Similarly, there are 227 data that are not experiencing financial distress (successful company). However, the exact prediction by the model is only 220 data. The level of classification accuracy was $96.9 \%$. The remaining 7 companies are improperly predicted by the model. This amount is equivalent to $2.59 \%$ and referred to the error type 2. Overall, the level of prediction accuracy model is amounting to $93.7 \%$.

Coefficient significance test is conducted to test whether any impact of independent variables to the dependent variable. In other words, this test represents decision on acceptance or rejection of $\mathrm{H}_{\mathrm{a}}$. Coefficient significance test results can be seen as follows. 
Table 4 Hypothesis Testing

\begin{tabular}{cccc}
\hline Variable & Coefficient (B) & Sig. & Decision \\
\hline WCR & -4.727 & 0.064 & $\mathrm{H}_{\mathrm{a}}$ rejected \\
CR & 0.664 & 0.007 & $\mathrm{H}_{\mathrm{a}}$ accepted \\
DTA & -1.210 & 0,239 & $\mathrm{H}_{\mathrm{a}}$ rejected \\
CLA & 0.194 & 0.940 & $\mathrm{H}_{\mathrm{a}}$ rejected \\
ROA & -52.248 & 0.000 & $\mathrm{H}_{\mathrm{a}}$ accepted \\
ROE & -0.951 & 0.239 & $\mathrm{H}_{\mathrm{a}}$ rejected \\
NPM & 0,170 & 0.943 & $\mathrm{H}_{\mathrm{a}}$ rejected \\
TATO & -1.671 & 0.141 & $\mathrm{H}_{\mathrm{a}}$ rejected \\
CFR & -1.984 & 0.007 & $\mathrm{H}_{\mathrm{a}}$ accepted \\
OCM & 0.277 & 0.878 & $\mathrm{H}_{\mathrm{a}}$ rejected \\
Constant & -0.013 & 0,991 & \\
\hline
\end{tabular}

Based on the above data processing, the logistic regression equation can be formed into:

$\operatorname{Ln}(P / 1-P)=-0.013-4.727 \mathrm{WCR}+0,664 \mathrm{CR}$ - 1.210 DTA - 52.248 ROA - 0.951 ROE + 0.170 NPM - 1.671 TATO - 1.984 CFR + $0.277 \mathrm{OCM}+\mathrm{e}$

Current ratio (CR) with sig. of 0.007 indicates that the current ratio has an effect to the financial distress. This decision was taken because the sig.value is less than 0.05 , so that $\mathrm{H}_{a}$ is accepted. Positive coefficient value of 0.664 indicates that the current ratio has positive influence to financial distress. According to the results above, the higher the value of the current ratio indicates the higher possibility of companies will be experiencing financial distress. This can happen when a company has much current assets rather than fixed assets. The quality of current assets is also illiquid. Some illiquid current assets are inventories of merchandise that is difficult to sold, trade receivables that are difficult to billed, excessive prepaid expenses, and quickly impaired shortterm investments. Therefore, not all current assets can be converted into cash quickly and will cause the difficulty to meet the demands of short-term creditors, in other words, the possibility of financial distress will arise if company has much current assets (Pranowo et al., 2010).
Return on assets (ROA) with sig. of 0.000 indicates that the return on assets has an effect the company's financial distress. This decision was taken because the sig. value is less than 0.05 , so that $\mathrm{H}_{a}$ is accepted. The negative coefficient of 52.248 indicates that the return on assets has a negative effect on the company's financial distress. According to the results above, the higher the value of return on assets indicates the lower possibility of financial distress. This situation happens since the higher return on assets will make the companies more efficient and effective in managing their assets (Hapsari, 2012). Decision to spend funds into productive assets will create higher profit for the company. If the company's management make a decision to spend their fund into nonproductive assets, such as investments in bonds when the company is expanding, it is unwise decision. Whereas, it is wiser to spend the fund in the form of buildings, equipment, or machinery, in order to support the development of the company expansion. Proper asset management will cause the decreasing expense and lead the company to earn a lot of savings. This would make the lower likelihood of financial distress.

Cash flow ratio (CFR) with sig. 0.007 indicates that the cash flow ratio has an effect to the company's financial distress. This decision was taken because the sig. value is less than 0.05 , so that $H_{a}$ is accepted. The negative 
coefficient of 1.984 indicates that the cash flow ratio has negative effect to the condition of financial distress. According to the results above, the higher value of the cash flow ratio will cause the company's financial distress is getting lower. Companies with high cash flow ratio, means that the company has earn positive operating cash flow to meet its short-term debt. Operating cash flow is cash flow sourced from the company's daily activities that reflects the availability of daily cash. Positive operating cash flow reflects the excess operating cash inflow after deducting cash disbursement. Therefore, the higher operating cash flow indicates the company's ability to create resources to meet the demands of short-term creditors so that the possibility of financial distress can be minimized (Atieh, 2014).

\section{CONCLUSIONS}

The results of the study showed (1) working capital ratio, debt-to-assets ratio, current liabilities to assets ratio, return on equity, net profit margin, total asset turnover, and operating cash margin do not significantly affect the condition of financial distress; (2) Current ratio, return on assets, and cash flow ratio significantly affect the company's financial distress condition. Specifically, the current ratio has the positive influence, while return on assets and cash flow ratio have negative influence to the financial distress condition.

This study has some limitations that may affect the results. These limitations as well as recommendations for further research are as follows (1) The sample in this study is only manufacturing company listed on the Indonesia Stock Exchange, so that the results cannot be generalized to all group companies; (2) Testing factors or independent variables only consist of working capital ratio, current ratio, debt-toassets ratio, current liabilities to assets ratio, return on assets, return on equity, net profit margin, total asset turnover, cash flow ratio and operating cash margin, so that the results would be different if the number of variable is augmented. For further research, good corporate governance or intellectual capital can be used as independent variable; (3) This research is only done for three years from 2011 to 2013 and using sample companies which is listed consecutively in the Indonesia Stock Exchange during 2009 to 2013. The results will be more accurate if the study period is extended; (4) This study is only used sample of 90 companies or 270 financial statement data. This amount is only a small fraction of the companies listed on the Indonesia Stock Exchange.

\section{REFERENCES:}

Al-khatib, Hazem B. and Alaa Al-horani. 2012. Predicting Financial Distress of Public Companies Listed in Amman Stock Exchange. Europian Scientific Journal, July edition Vol. 8, No. 15, ISSN: 1857-7881.

Almilia, Luciana Spica. 2006. Prediksi Kondisi Financial Distress Perusahaan Go-Public dengan Menggunakan Analisis Multinomial Logit. Jurnal Ekonomi dan Bisnis, Vol. 12, No.1, ISSN: 0854-9087.

Almilia, Luciana Spica and Emanuel Krsitijadi. 2003. Analisis Rasio Keuangan untuk Memprediksi Kondisi Financial Distress Perusahaan Manufaktur yang Terdaftar di Bursa Efek Jakarta. Jurnal Akuntansi dan Auditing Indonesia, Vol. 7, No. 2, ISSN: 1410-2420.

Atieh, Sulayman H. 2014. Liquidity Analysis Using Cash Flow Ratios as Compared to Traditional Ratios in Pharmaceutical Sector in Jordan. International Journal of Financial Research, Vol.5, No. 3, ISSN: 19234023.

Endri. 2009. Prediksi Kebangkrutan Bank untuk Menghadapi dan Mengelola Perubahan Lingkungan Bisnis: Analisis Model Altman's Z-Score. Perbanas Institute Repository, Vol. 2, No. 1, ISSN: 1978-9017. 
Ghozali, Imam. 2013. Aplikasi Analisis Multivariate dengan Program IBM SPSS 21 Update PLS Regresi. Semarang: Badan Penerbit Universitas Diponegoro.

Hapsari, Evanny Indri. 2012. Kekuatan Rasio Keuangan dalam Memprediksi Kondisi Financial Distress Perusahaan Manufaktur di BEl. Jurnal Dinamika Manajamen Universitas Negeri Semarang, Vol. 3, No. 2: 101-109, ISSN: 2086-0668.

Hidayat, Muhammad Arif and Wahyu Meiranto. 2014. Prediksi Financial Distress Perusahaan Manufaktur di Indonesia. Diponegoro Jurnal of Accounting, Vol. 3, No. 3: 1-11, ISSN: 2337-3806.

Juniarti. 2013. Good Corporate Governance and Predicting Financial Distress Using Logistic and Probit Regression Model. Jurnal Akuntansi dan Keuangan, Vol. 15, №. 1: 43-50, ISSN 1411-0288.

Kasgari, Ahmad Ahmadpur, Seyyed Hasan Salehnezhad, and Fatemeh Ebadi. 2013. A Review of Bankruptcy and its Prediction. International Journal of Academic Research in Accounting, Finance, and Management Sciences, Vol. 3, No. 4: 274-277. ISSN: 2308-0337.

Ohlson, James A. 1980. Financial Ratio and the Probabilistic Prediction of Bankruptcy. Journal of Accounting Research, Vol.18, No.1: 109-131.

Pasaribu, Rowland Bismark Fernando. 2008. Penggunaan Binary Logit untuk Prediksi Financial Distress Perusahaan yang Tercatat di Bursa Efek Jakarta. Jurnal Ekonomi, Bisnis, dan Akuntansi Ventura, Vol. 11, No. 2: 153-172), ISSN: 1410-6418

Pranowo, Koes, Noer Azam Achsani, and Nunung Nuryartono. 2010. Determinant of Corporate Financial Distress in an Emerging Market Economy: Empirical from the Indonesian Stock Exchange 2004-2008. International Research Journal and Economics, ISSN: 1450-2887.

Saleh, Amir and Bambang Sudiyanto. 2013. Pengaruh Rasio Keuangan untuk Memprediksi Probabilitas Kebangkrutan Pada Perusahaan Manufaktur yang Terdaftar di Bursa Efek Indonesia. Dinamika Akuntansi, Keuangan, dan Perbankan, Vol. 2, No. 1: 82-91, ISSN: 1979-4878

Subramanyam, K. R. and John J. Wild. 2009. Financial Statement Analysis. New York: McGraw-Hill Companies Inc.

Weygandt, Jerry J., Paul D. Kimmel, and Donald E. Kieso. 2013. Financial Accounting IFRS Edition. 